\title{
Evaluation of Four S-Triazine Herbicides for Early Weed Control in Grain Sorghum ${ }^{1,2}$
}

\author{
Luis Almodóvar-Vega
}

\begin{abstract}
Four s-triazine herbicides were evaluated for weed control in grain sorghum (Sorghum bicolor L.) at the Lajas Research and Development Center farm in 1975. Preemergence herbicides were evaluated alone and in mixtures. The chemicals 2-chloro-4-(ethylamino)-6-(isopropylamino) $s$-triazine [Atrazine] at $3.36 \mathrm{~kg}$ a.i./ha, 2-chloro-4, 6-bis (isopropylamino)-s-triazine [Propazine] at 4.48 $\mathrm{kg} \mathrm{a.i./ha,} \mathrm{and} \mathrm{the} \mathrm{mixture} \mathrm{of} \mathrm{Atrazine} \mathrm{plus} \mathrm{2-(tert-butylamino)-4-(ethylamino)-}$ 6-(methylthio)-s-triazine [Terbutryn] at $1.68 \mathrm{~kg}$ a.i./ha each resulted in significant grain yields $(P=0.05)$ similar to the hand-weeded plots. Atrazine alone was efficient in controlling grass weeds, and when mixed with Terbutryn in controlling broadleaves. Although the hand-weeded check was the highest grain yielder of all treatments there was no statistical difference among handweeding and the herbicide treatments, Atrazine, Propazine, and Atrazine plus Terbutryn. Johnson grass (Sorghum halepense L.) was an aggressive competitor weed and could not be controlled effectively with the chemicals evaluated.
\end{abstract}

\section{INTRODUCTION}

The rising cost and shortage of labor have stressed the importance of chemical weed control in crop production. Puerto Rico's tropical environwent provides a favorable climate for exhuberant vegetation growth most of the year. Under these conditions weeds compete with crops reducing yields and quality.

Sorghum (Sorghum bicolor L.) offers a great potential for human consumption and as a component for animal feeds. Much of the sorghum grown in the Island is the "Blanco del Pais" cultivar, grown solely for forage. Herbicide evaluation studies to determine the feasibility of using chemicals for preemergence weed control is an important component of the technological package of practices that must be developed for sorghum production in the tropics.

Miller et al. ${ }^{4}$ at Mayagüez, Puerto Rico found that 2-chloro-4 (ethylamino)-6-(isopropylamino)-s-triazine [Atrazine] and 2-chloro-4,6-bis (isopropylamino)-s-triazine [Propazine] at $3 \mathrm{lb} /$ acre controlled weeds effectively in sorghum although some injury resulted from Atrazine. Herbicide

1 Manuscript submitted to Editorial Board September 13, 1983.

${ }^{2}$ Work conducted under Contract No. AID/TA-C-1087, "Development of Improved High Yielding Sorghum Cultivars."

${ }^{3}$ Research Associate in Weed Science, Crop Protection Department, University of Puerto Rico, Agricultural Experiment Station, Mayagüez Campus and Administrator of Lajas Research and Development Center.

${ }^{4}$ Miller, F. R., H. J. Cruzado, R. W. Bovey and C. C. Dowler, 1969. Weed control for growing sorghum in Puerto Rico, J. Agric. Univ. P.R. 53:199-206. 
mixtures were not investigated. In Hungary, Kukedi, ${ }^{5}$ studied sorghum weed control for 10 years. Propazine and Atrazine were used successfully from 2.5 to $3 \mathrm{~kg} / \mathrm{ha}$.

\section{MATERIALS AND METHODS}

Grain sorghum cultivar 4166 was seeded on April 28, at the Lajas Research and Development Center farm. The experiment followed a randomized complete block design with four replications and was established on a Vertisol (Fraternidad clay soil). Plot size was 1.83 m wide (2 rows) and $6.10 \mathrm{~m}$ long. There were blank rows between plots and $92 \mathrm{~cm}$ alleyways at each end. A 15-5-10 N-P-K fertilizer was banded at the rate of 2.24 metric tons per hectare.

On April 29, the preemergence herbicides were sprayed with a compressed-air field plot sprayer set at $2 \mathrm{~kg} / \mathrm{cm}^{2}$, equipped with 8005 Teejet $^{6}$ tips, delivering one liter of herbicide preparation per plot.

Treatments were as follows: 1) Atrazine at $3.36 \mathrm{~kg}$ a.i./ha; 2) Propazine ${ }^{7}$ at $4.48 \mathrm{~kg} ; 3$ ) Terbutryn, 2-(tert butylamino)-4-(ethylamino)-6-methylthio)-s-triazine at $3.36 \mathrm{~kg}$; 4) Atrazine plus Propazine at $1.68+2.24 \mathrm{~kg}$; 5) Atrazine plus Terbutryn at $1.68 \mathrm{~kg}$ each; 6) Propazine plus Terbutryn at $2.24+1.68 \mathrm{~kg} ; 7$ ) hand-weeded check; 8) non-weeded check; and 9) Hexazinone, 3-cyclohexyl-6-(dimethylamino)-1-methyl-1,3,5,-triazine$2,4(1 \mathrm{H}, 3 \mathrm{H})$-dione at $1.12 \mathrm{~kg} / \mathrm{ha}$.

The hand-weeded plots were cultivated on May 14. All plots, except non-weeded checks, were mechanically cultivated on May 27 to control Johnson grass (Sorghum halepense L.), which was tolerant to the herbicides tested. The field used for this trial was heavily infested with Johnson grass seedlings and rhizomes, since this weed predominates in the area.

During the growth period, the experiment was furrow-irrigated three times (5 $\mathrm{cm}$ of water per application) to supplement $18 \mathrm{~cm}$ of rainfall. Malathion was applied twice to control insects attacking sorghum.

The experiment was harvested August 6, 1975, and the panicles threshed 1 week later for recording yields when grain averaged $13 \%$ moisture.

\section{RESULTS AND DISCUSSION}

Table 1 summarizes weed control data (except for Johnson grass) and grain sorghum yields. Atrazine (3.36 kg), Propazine $(4.48 \mathrm{~kg}$ ), and Atra-

${ }^{5}$ Kukedi, E., Ten years (1955-1965) of chemical weed control in sorghum, Acta Agric. Hung. Tomus XIV:309-20, 1965.

${ }^{6}$ Trade names are used only to provide specific information. Mention of a trade name does not constitute a warranty of equipment or materials by the Agricultural Experiment Station of the U.P.R., nor is this mention a statement of preference over other equipment or materials.

${ }^{7}$ All herbicides were applied based on active ingredient per hectare. 
zine plus Terbutryn (1.68 $\mathrm{kg}$ each) were as effective as the handweeded check regarding yields $(\mathrm{P}=0.05)$; the least effective herbicide was Hexazinone $(1.12 \mathrm{~kg})$. As expected, the hand-weeded check was the highest crop yielder since total weed competition was early suppressed. Also, some crop injury may have occurred with Atrazine and Propazine as has been reported by Miller and coworkers, causing a reduction in yield. In grass control, except Sorghum halepense, Atrazine was very effective and also outstanding for broadleaf control when combined with Terbutryn. Hexazinone $(1.12 \mathrm{~kg})$ was not an effective chemical for controlling weeds and also caused some injury to sorghum. Prevalent weeds in non-weeded plots were: junglerice, Echinochloa colonum (L.) Link; horse purslane, Trianthema portulacastrum L.; redroot pigweed,

TABLE 1.-Weed control and sorghum yields at Lajas, 1975

\begin{tabular}{|c|c|c|c|}
\hline \multirow{2}{*}{ Treatment ${ }^{1}$} & \multicolumn{2}{|c|}{ Weed control $^{2}$} & \multirow{2}{*}{ Average yield. } \\
\hline & Broadleaves & Grasses & \\
\hline kg a.i./ha & $\%$ & $\%$ & $\mathrm{~kg} / \mathrm{ha}$ \\
\hline Atrazine 3.36 & $80.0 \mathrm{~b}$ & $82.5 \mathrm{ab}$ & $2762.7 \mathrm{ab}$ \\
\hline Propazine 4.48 & $77.5 \mathrm{~b}$ & $60.0 \mathrm{~b}$ & $2244.3 \mathrm{abc}$ \\
\hline Terbutryn 3.36 & $65.0 \mathrm{c}$ & $57.5 \mathrm{~b}$ & $1695.5 \mathrm{bc}$ \\
\hline $\begin{array}{l}\text { Atrazine + Propazine } \\
1.68+2.24\end{array}$ & $80.0 \mathrm{~b}$ & $67.5 \mathrm{~b}$ & $1685.3 \mathrm{bc}$ \\
\hline $\begin{array}{l}\text { Atrazine + Terbutryn } \\
1.68+1.68\end{array}$ & $86.0 \mathrm{ab}$ & $75.0 \mathrm{~b}$ & $2972.2 \mathrm{a}$ \\
\hline $\begin{array}{l}\text { Propazine + Terbutryn } \\
2.24+1.68\end{array}$ & $82.5 \mathrm{ab}$ & $70.0 \mathrm{~b}$ & $1481.6 \mathrm{bc}$ \\
\hline Hand-weeded & $100.0 \mathrm{a}$ & $100.0 \mathrm{a}$ & $3230.2 \mathrm{a}$ \\
\hline Non-weeded & $0.0 \mathrm{~d}$ & $0.0 \mathrm{c}$ & $221.7 \mathrm{~d}$ \\
\hline Hexazinone 1.12 & $70.0 \mathrm{~b}$ & $57.5 \mathrm{~b}$ & $1431.2 \mathrm{c}$ \\
\hline
\end{tabular}

${ }^{1}$ All treatment plots, except the non-weeded check, received a late cultivation to control Johnson grass, which was not controlled effectively by the herbicides used.

${ }^{2}$ Means of four replications based on visual ratings of weed populations recorded on May 14. Values in columns followed by the same letters do not differ significantly at $\mathrm{P}=$ 0.05 , Duncan's multiple range test.

Amaranthus dubius L.; niruri, Phyllantus niruri L.; morning glory, Ipomoea spp; and spurge, Euphorbia heterophylla L. Weed control ratings of different species based on visual observations were recorded for the first 3 weeks only because of Johnson grass severe competition.

\section{RESUMEN}

En un estudio realizado en Lajas se evaluaron cuatro herbicidas (triazinas simétricas) por separado y en mezclas entre si para controlar malezas en sorgo de grano durante el 1975. Los herbicidas fueron Atrazine, Propazine, Terbutryn y Hexazinone. Con todos los herbicidas se obtuvieron rendimientos significativamente $(P=0.05)$ más elevados que el del testigo no desyerbado. 
Las parcelas tratadas con Atrazine a $3.36 \mathrm{~kg}$ i.a./ha fueron similares en rendimiento $(P=0.05)$ a las parcelas testigo desyerbadas a mano.

En las parcelas desyerbadas a mano se obtuvieron los rendimientos más altos posiblemente debido a la eliminación de la competencia temprana de la yerba Johnson (Sorghum halepense L.), la posible toxicidad de los herbicidas en las parcelas tratadas y la pérdida de herbicidas por arrastre debido al riego por surcos, lo que posiblemente afectó el control de malezas.

Atrazine (3.36 kg i.a./ha) demostró ser un herbicida eficaz para controlar gramíneas, excepto la yerba Johnson y para controlar malezas de hoja ancha al mezclarlo con Terbutryn.

La yerba Johnson fue la maleza que ofreció más competencia al sorgo de grano por ser altamente resistente a los herbicidas utilizados. 